\title{
A unified approach to domains in word- and phrase-level phonology
}

\author{
Gísli Rúnar Harðarson*
}

\begin{abstract}
This paper discusses parallels between the conditioning of phonological processes at the word- and phrase-level. The approach taken here is a direct reference approach in which apparent mismatches between morphosyntactic domains and phonological domains are derived from the spell-out procedure. The analysis relies on two main ingredients, i) inclusion of the output of spell-out in subsequent cycles, and ii) layering of concatenation. Under (i), the phonological output of spell-out is visible and can be affected, however the internal structure is not. This can yield the effects of phonological domains extending beyond the morphosyntactic domain. Under (ii), processes are specified to apply at either early or late concatenation, where early and late concatenation are determined by the selectional relationship between the elements, limiting the application of phonological processes within the spell-out domain. This is first illustrated by the application of umlauts in Icelandic and then this approach is extended to penultimate vowel lengthening (PVL) in Zulu. Finally I argue that the variable phrasing of DPs with respect to PVL is due to the heads in the extended nominal projection being specified to form a complex head: When two unmodified heads specified to form a complex head are merged, the resulting projection yields a complex head directly. If one of the heads is modified, i.e. it has already projected to a phrase, the resulting projection must be phrasal and the two heads must form a complex head post-syntactically.
\end{abstract}

Keywords. syntax; morphology; phonology; morphosyntax-phonology interface; compounding; umlaut; penultimate vowel lengthening; Icelandic; Zulu

1. Introduction. Although the significance of cyclic morphosyntactic domains for the application of phonological processes has been well established both at the phrasal-level (see, e.g., Chomsky 2001; Adger, David 2007; Kahnemuyipour 2009; Kratzer \& Selkirk 2007; D’Alessandro \& Scheer 2015; Zubizarreta \& Vergnaud 2017) as well as the word-level (see, e.g., Marvin 2002, 2013; Piggott \& Newell 2007; Newell 2008; Embick 2010, 2013, 2014; Ingason \& Sigurðsson 2015; Moskal 2015), there are a number of instances where the morphosyntactic domain appears to be either too large or too small (see, e.g., Pak 2008; Selkirk 2011; Cheng \& Downing 2016; Harðarson 2016, 2017; Sande \& Jenks 2018).

Mismatches such as these have been traditionally been used as arguments for an indirect reference approach, where phonological domains are computed from an intermediate structure produced from the output of syntax (e.g., Hayes 1990; Nespor \& Vogel 2007; Selkirk 2011; Cheng \& Downing 2016). In this paper, I argue that the apparent mismatches can be computed directly from the morphosyntactic structure under two assumptions regarding the spell-out procedure: i) the phonological string put out by previous cycles is included in the computation of subsequent cycles (cf. Kiparsky 1982; Kaisse 1985; Sande \& Jenks 2018), and ii) layering of the derivation, where elements in selectional relationship are concatenated first, followed by the concatenation non-selected elements (drawing on, e.g., Kiparsky 1982; Monahan 1982; Pak

${ }^{*}$ This research was supported by the Icelandic Research Fund, grant no. 173959-051. Author: Gísli Rúnar Harðarson, University of Iceland (grh@ @i.is). 
2008). ${ }^{1}$ To illustrate this approach I will examine, at the word-level, umlauts in Icelandic, and, at the phrase-level, penultimate vowel lengthening (PVL) in Zulu.

This paper is organized as follows: In section 2, I discuss the relevant properties of umlauts in Icelandic. In section 3, I discuss the relevant properties of the spell-out procedure with respect to the application of umlauts. In section 4, I extend this approach to PVL in Zulu. In section 5, the main points of the paper are summarized.

2. Umlaut in Icelandic. Umlaut refers to a morphologically conditioned vowel alternation that (for the most part) applies inconsistently across items and contexts (e.g., Anderson 1969; Kiparsky 1984; Árnason 1985; Ingason 2016; Embick \& Shwayder 2018, and many others). Starting with the i-umlaut, the vowel alternations are shown in table 1.

\begin{tabular}{|c|c|c|}
\hline Underlying form & & Surface form \\
\hline $\mathrm{a} / \mathrm{a} /, \mathrm{o} / \mathrm{\jmath} /, \ddot{\mathrm{o}} / œ /$ & $\rightarrow$ & $\mathrm{e} / \varepsilon /$ \\
\hline á /au/,ó /ou/ & $\rightarrow$ & $æ / \mathrm{ai} /$ \\
\hline $\mathrm{u} / \mathrm{y} /, \mathrm{o} / \mathrm{o} /$ & $\rightarrow$ & $\mathrm{y} / \mathrm{I} /$ \\
\hline ú /u/, jú /ju/, jó /jou/ & $\rightarrow$ & ý /i/ \\
\hline $\mathrm{au} / œ y /$ & $\rightarrow$ & ey /ei/ \\
\hline
\end{tabular}

Table 1. vowel alternations in i-umlaut (Árnason 2011:24, ad.)

The i-umlaut targets the closest vowel of the target preceding the trigger. If there is no intervening vowel, the umlaut can freely cross an overt category node intervening between the trigger and the target (Harðarson 2016 et seq.). This is shown in (1), where the adjective in (1b) is derived from the noun in (1a) with the $-u g$ suffix. The adjective is then nominalized in (1c) with the suffixation of the $-i$ nominalizer. The nominalizer triggers both syncope on - $u g$ and $i-$ umlaut on the root. ${ }^{2}$ (2) shows the inconsistencies of the application of i-umlaut as it does not apply in auðgi- although it follows the same derivation pattern as mál-.
b. mál- $\emptyset$ - ug- speech- n- a- 'talkative'
b. auð- $\emptyset$ - ug-
wealth- n- a- 'rich'
c. mæl- $\emptyset$-g-i- speech- n- a- n- 'talkativeness'
c. auð/*еуð- $\emptyset$ - g- i- wealth- n- a- n- 'wealth'

The structure of (1c) includes three category morphemes, each serving as a domain definer (cf. Marantz 2001, 2007). This is shown in (3) below.

(3) The structure of mælgi

$$
\text { [n [a }[n \underset{\text { SPEECH }}{\sqrt{\text { target }}} n-] \text { a- }] \text { n- }]
$$

\footnotetext{
${ }^{1}$ Spell-out should not be confused with the notion of Transfer. Assuming an architecture in the vein of, e.g., Embick \& Noyer (2001); Embick (2010) and others, I take the former to refer to the translation of the hierarchical structure to a phonological string and the latter to refer to the shipping of the narrow syntactic structure to LF or PF, where it is potentially subject to manipulation of the hierarchical structure prior to spell-out (cf. Chomsky 1995).

${ }^{2}$ Note that syncope is not phonologically conditioned in this case, as, e.g., the weak masculine nominative singular - $i$, though homophonous to the nominalizer in question, does not trigger i-umlaut: mál-ug-i and not *mál-g-i.
} 
The i-umlaut must then apply across two domains in order to reach the root. Hence in this case, the morphosyntactic domain is too small for the application of i-umlaut.

U-umlaut refers to the vowel alternations shown in table 2 (e.g., Árnason 1985; Ingason 2016). Unlike the i-umlaut, it applies throughout the stem as long as there is a chain of potential undergoers, i.e. /a/, (4). Note that the u-umlaut applies consistently in the context of the dative -um suffix.

\begin{tabular}{|c|c|c|}
\hline UR & & SR \\
\hline $\mathrm{a} / \mathrm{a} /$ & $\rightarrow$ & ö /œ/ \\
\hline $\mathrm{a} / \mathrm{a} /$ & $\rightarrow$ & $\mathrm{u} / \mathrm{y} /$ or $/ \mathrm{o} /$ \\
\hline
\end{tabular}

Table 2. Vowel alternations in u-umlaut
a. bak- ar- $\mathrm{i}$
b. bök- ur- um
c. bjarn- ar
d. björn- um
bake- n- NOM.SG
'baker'
bear- GEN.SG
'bear'
bear- DAT.PL

However, in compounds, when the dative suffix triggers u-umlaut on the head of the compound, it does not apply across the boundary between the two elements, (5). The structure assumed for the compound is provided in (6).

$$
\begin{aligned}
& \text { a. bjarn \# bök- ur- um } \\
& \text { bear \# bak- er- DAT.PL } \\
& \text { 'bear bakers' }
\end{aligned}
$$

$$
\begin{aligned}
& \text { b. *björn \# buk- ur- um } \\
& \text { bear \# bak- er- DAT.PL }
\end{aligned}
$$

Other processes contained by morphosyntactic domains are known to occur in these contexts, such as impoverishment or contextual allomorphy (see Fenger \& Harðarson 2018; Harðarson 2018, to appear), indicating that the two elements of the compound are indeed contained within the same cyclic domain (cf. Moskal 2015). Hence the blocking of the u-umlaut is not expected and the morphosyntactic domain appears too large in case of compounds.

3. Spelling out structures. Harðarson (2016 et seq.) relates the effects of the umlauts (and other processes) to extended projections where the domain of morphophonology is marked by the highest functional projection in the extended projection of the root. The definition of the extended projection of the root utilizes a modified version of Grimshaw (2000) requiring a chain of morphologically selected functional heads. This, however leaves open the question as to why this would be the case. Harðarson (to appear) addresses this question by examining the spell-out procedure, i.e. the transformation of a hierarchical structure to a linear string. There the effects observed in the previous section are argued to follow from two main ingrediants: i) the phonological string resulting from spell-out is included in the spelling-out of subsequent cycles (following, e.g., Kaisse 1985; Bobaljik 2000; Sande \& Jenks 2018), ii) layering of concatenation (drawing on, e.g. Kiparsky 1982; Monahan 1982; Pak 2008), and additionally, iii) the assumption that morphophonological and phonological processes apply at the point of concatenation (cf. Kiparsky 1982; Monahan 1982; Pak 2008). Under these assumptions, it is possible to achieve the effects described for the umlauts in Icelandic, described in the previous section. In the following two subsection I illustrate this through the derivation of maelgi 
'talkativeness' and bjarnbökurum 'bear baker-DAT.PL' respectively.

3.1. TOO SMALL. The structure of maelgi is shown in (3) above, repeated here as (7). As was discussed above, the outer $n$ appears to trigger i-umlaut across two morphosyntactic domains defined by the inner $n$ and $a$.

(7) The structure of mælgi

$$
\text { [n }[\text { a }[n \sqrt{\text { SPEECH }} n-] \text { a- }] \mathbf{n}-]
$$

I assume here that the structure is spelled out cyclically from the root outward (Bobaljik 2000), and a locality domain the vein of Moskal (2015), where spell-out is triggered by a cyclic head, which is also visible to the item undergoing spell-out. The first step in spelling out the structure is inserting the vocabulary item for the root $\sqrt{\mathrm{SPEECH}},(8)$. In the subsequent cycle, the inner $n$ is spelled out, (9). I follow Noyer (1997) in that vocabulary insertion precedes linearization (contra Embick 2010). Following vocabulary insertion, $n$ is linearized with respect to its complement, i.e. the phonological string created in the previous cycle (cf. Kiparsky 1982; Kaisse 1985; Bobaljik 2000; Sande \& Jenks 2018), and two items are then concatenated (Embick 2010). These steps have been conflated in (8) and (9) but will be shown for subsequent cycles.
(8) First cycle
$[n / \mathrm{maul} / n$ ]
(9) Second cycle
[a $[n / \mathrm{maul} / \sim \emptyset]$ a $]$

In the third cycle $a$ is spelled out, (10). Following Bobaljik (2000), vocabulary item replaces a feature bundle, a null morpheme is then only visible as long as its morphosyntactic features are visible and so the inner $n$ is only visible in the first three cycles and is effectively pruned following concatenation in (10c).

(10) Third cycle
a. Step 1: Vocabulary insertion $[\mathrm{n}[\mathrm{a}[\mathrm{n} / \mathrm{maul} /-\emptyset] / \mathrm{Yy} /] \mathrm{n}]$
b. Step 2: Linearization
[n $[\mathrm{a}[\mathrm{n} / \mathrm{maul} /-\emptyset] * / \mathrm{yy} / \mathrm{n} \mathrm{n}]$
c. Step 3: Concatenation
[n $[\mathrm{a} / \mathrm{maul} / / \mathrm{yy} / \mathrm{n} \mathrm{n}]$
d. Output
[n [a /maulyy/ ] n ]

The fourth cycle spells out the outer $n$, (11). At the point of concatenation, two processes affecting the previously spelled out string are triggered: first syncope, (11d), followed by iumlaut, (11e). Note also that syncope feeds occlusion.

(11) Fourth cycle
a. Vocabulary insertion
[n [a/maulyy/ ] / I/ ]
b. Linearization
[n [a/maulyy/ ] $* / \mathrm{I} /$ ]
c. Concatenation
$[\mathrm{n} /$ maulyy $/ / / \mathrm{I} /]$
d. Syncope [n $/$ maulk/ $/ \mathrm{I} /$ ]
e. i-umlaut [n $/$ mailk/ / / / ]
f. Output [n/mailki/ ]

The mismatch between the mophosyntactic domains and the domain of morphophonology is hence only apparent. The inclusion of the output of previous cycles allows for an interaction between the output and higher items, however, these items can only target the edge of the string or the entire string and, crucially, do not have access to internal morphosyntactic com- 
position to the string (cf. Kiparsky 1982; Kaisse 1985; Sande \& Jenks 2018).

3.2. TOO LARGE. In case of compounds, the spell-out domain appears to be too large, as can be seen from the application of u-umlaut discussed in section 2. I argue that this effect is due to layering of spell-out. Drawing on Pak (2008), I argue that the timing of concatenation differs, where elements in a selectional relationship are subject to early concatenation whereas elements not in a selectional relationship are subject to late concatenation. Also, I assume that processes are specified for application at either early or late concatenation (cf. Kiparsky 1982; Monahan 1982; Pak 2008). I argue here that umlauts are specified to apply at early concatenation. This will be illustrated through the derivation of bjarnbökurum 'bear baker-DAT.SG'. The structure shown in (6) is repeated here as (12).

$$
\begin{aligned}
& \text { The structure of bjarnbökurum } \\
& {[[\mathbf{n}[n \sqrt{\mathrm{BEAR}} n][\mathbf{n} \sqrt{\mathrm{BAKE}} \mathbf{n}]] \text { DAT.PL }]}
\end{aligned}
$$

As mentioned above, there is evidence that the two elements of the compound are contained within the same morphosyntactic domain, hence, under the assumption that spell-out occurs from the root outwards, both elements of the compound are expected to undergo spell-out simultaneously, as there are two roots in the structure. The output of the first steps is shown in (13) below.

$$
\begin{array}{ll}
\text { a. } & {[[\mathbf{n}[n / \operatorname{pjatn} / n][\mathbf{n} / \operatorname{pak} / \mathbf{n}]] \text { DAT.PL }]} \\
\text { b. } & {[[\mathbf{n}[n / \operatorname{pjatn} / \sim \emptyset][\mathbf{n} / \operatorname{pak} / / / \operatorname{ar} /]] \text { DAT.PL }]}
\end{array}
$$

This point in the derivation marks the end of the extended projection of 'bear', i.e. there are no other elements that morphologically select for or are morphologically selected by an element in it's extended projection and hence further concatenation is suspended. ${ }^{3}$ 'Baker', on the other hand, is in a selectional relationship with the head carrying number and case, and the derivations continues. The suffix $-u m$ is inserted, (14a) and it is linearized with respect to its complement, (14b) and subsequently concatenated with the string / pakar/, (14c). I argue that the umlauts are specified to apply at early concatenation and hence the suffix -um triggers umlaut at this point, (14d). The non-head element, bjarn- has not been concatenated with the string that is affected and is hence subject to umlaut. This marks the end of early concatenation and late concatenation is subsequently applied, (14e), ultimately, yielding the phonological string in (14f).
a. Vocabulary insertion
d. U-umlaut [ [n [n /pjatn/-Ø] [n /pakar/ ]] /Ym/ ]
b. Linearization

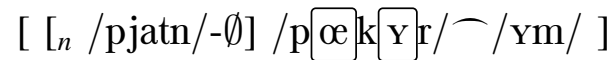 $[$ [n $[n / p j a t n /-\emptyset][n / p a k a r /]] * / Y m /]$
c. Early concatenation [ [n/pjatn/-Ø] /pakar/ / / Ym/ ] 
hence only apparent as both early and late concatenation apply within the same morphosyntactic domain.

4. Beyond the complex head. Penultimate vowel lengthening (PVL) provides a good testing ground for the extension of this approach beyond the complex head. Here I will discuss PVL in Zulu as discussed by Cheng \& Downing (2007 et seq.). In simple cases, the domain of PVL appears to span the entire sentence, (15). The apparent domain for PVL is indicated by round brackets. As is shown below, a single application of PVL is observed in a simple SVO sentence, (15a), double object construction with a topicalized indirect object, (15b), and even including a complement clause, (15c). In each case, it appears that an entire sentence, each of which containing multiple morphosyntactic domains, forms a single domain for PVL. ${ }^{4}$

Zulu (Cheng \& Downing 2007; 53)

a. [CP (ízin-g'áne zi-hlúph' [

10-child 10SUBJ-bother 7-old.woman

'The children are bothering the old woman.'

b. [CP (ízi-vakáshi [C’' ngi-zi-phekél' [ „v í-ny a: ma) ]]]

10-visitor I-10OBJ-cook.for 9-meat

'The visitors, I am cooking some meat.'

c. [CP (Si-khólwa [CP úkúth’ ábá-ntwána bá-dlalá ph á: ndle)]]

we-believe that 2-child 2-play outside

'We believe that the children are playing outside.'

Here the morphosyntactic domain clearly appears to be too small as each sentence includes multiple domains. Under the spell-out procedure outlined in the previous section, these cases receive a straight forward account. Consider the derivation of (15b), shown below. ${ }^{5}$ I assume that PVL applies at the end of early concatenation and the target at each cycle is marked by a box. In the first cycle the complement of $v$ is spelled out, (16a), which in this case only includes the direct object. The second cycle spells out the complement of C, i.e. TP, (16b). As the derivation includes the output of the previous cycle, the target of PVL has already undergone lengthening and further lengthening is blocked, presumably by phonotactic constraints. Finally, the CP is spelled out and the topicalized element is concatenated with the output of the previous cycle, (16c). Again, the target for PVL has already undergone lengthening and further lengthening is blocked.

Spell-out of (15b)

a. Spell-out of VP b. Spell-out of TP

[тр /ngiziphekél'///íny a: $\mathrm{ma} /]$

c. Spell-out of CP

[CP /ízivakáshi/_/ngiziphekél'íny a:ma/]

Under this approach it is no longer necessary to associate PVL specifically with CP (contra

\footnotetext{
${ }^{4}$ Few caveats are in order. First, I assume that the verb raises out of the vP, however, I leave open as to how high it raises, i.e. to a head between T and v (e.g., Julien 2002; Buell 2005) or perhaps higher. Second, the number of domains assumed in the clausal spine may prove too simplistic, as aspectual heads appear to serve as domain definers (see, e.g., Wurmbrand 2014) and that domains appear to be defined dynamically (e.g., Bobaljik \& Wurmbrand 2005, 2013; Bošković 2013). These issues do have wide ranging consequences for the syntactic analysis, but lie far beyond the scope of this paper.

${ }^{5}$ The role of D and reasons for why it is not factoring into the application of PVL in (15) will be discussed below.
} 
Cheng \& Downing 2007 et seq.). PVL applies at every cycle, however, only a single application is visible when the PVL targets at each cycle line up. This is illustrated by the contrast between non-locative restrictive relative clauses in subject and object positions. When an object contains a relative clause, (17b), only a single application of PVL is observed. Under the spell-out procedure advocated here, at every cycle, the target of PVL is the same vowel as outlined above. When a subject contains the relative clause, (17a), two applications of PVL are observed: one within the relative clause, and one within the main clause.

Non-locative restrictive relative clauses (Cheng \& Downing 2007; 53)
a. ( [(ín-dod'é-gqoke ísí-gq o: ko)] í-bon-é ízi-vaká: shi) 9-man 9REL-wear 7-hat 9SUBJ-see-TAM 8-visitor
'The man who is wearing a hat saw the visitors.'
b. (si-thánd' [ísí-gqok' ín-dod' é-si-gqok-il ê:-yo])
we-like 6-hat 9-man 9REL-6OBJ-wear-TAM-REL
'We like the hat the man is wearing.'

This is expected as PVL is applied within the relative clause at prior to concatenation with the rest of the clause.

In a neutral context, adverbs phrase separately from the clause and each other, (18a), but in the absence of an object, the leftmost adverb appears to phrase with the verb, (18b) (Cheng \& Downing 2014). ${ }^{6}$

(18) Phrasing of adverbs (Cheng \& Downing 2014; 47)
a. [CP (ú-phúze [vP [vP [vP [vP í-kh o: fi)] (ngén[í:shi)] (f u: thi)]]]
1sUBJ-drank 5-coffee with.bowl again
'He drank coffee with a bowl again.'
b. [CP (ú-phékê [vP ka: le) (íz o: lo)]]
1sUBJ-cooked well yesterday
'He cooked well yesterday.'

Under the approach taken here, these effects follow. First consider the derivation of (18a), shown below. As in (16) above, the argument is targeted for PVL, however, the VP additionally contains the two adverbial phrases. As the three elements have not been concatenated with each other, and hence form three separate strings at the end of early concatenation, all three strings are targeted for PVL, (19a). ${ }^{7}$ Late concatenation applies subsequently, concatenating the noun and the two adverbs, (19b). During the spell-out of TP, the verb is concatenated with the phonological string resulting from the spell-out of VP, (19c). The vowel targeted has already undergone lengthening and further lengthening is blocked.

\footnotetext{
${ }^{6}$ Note that although I assume here that the relevant adverbs are adjoined to VP, the effects observed can be achieved under a number of attachment sites. I leave open here the question of where adverbs are ultimately adjoined as properly addressing it necessitates much a much deeper dive into various open questions regarding the clausal structure than fit within the scope of this paper.

${ }^{7}$ Alternatively, the adverbs may have undergone PVL in separate workspace prior to merging with the VP.
} 
a. VP: early concatenation [vP /íkh o: fi/ [AdvP /ngén [í:shi/] [advP /f u: thi/] ]

b. VP: late concatenation [vP /íkho:fi/_/ngéní:shi/_/fu:thi/ ]

c. TP: early concatenation [тр /úphúze/一/íkho:fingéní:shif u: thi/]

This offers the posibility to explain the pattern in (18a) and (18b) without having to assume a variability in the phrasing of the adverbs, i.e. that the leftmost element phrases with the verb (cf. Cheng \& Downing 2014), as the effects follow from the approach taken here. As discussed above, the adverbs are adjoined to VP, and hence subject to spell-out in a previous cycle. Adverbs are not selected, hence not subject to early concatenation with other elements within the spell-out domain and PVL applies to both adverbs, (20a). The adverbs are subsequently late concatenated, (20b), finishing the cycle. During the spell-out of TP. the verb is concatenated with the string resulting from the previous cycle, (20c). As above, the target for PVL has already undergone lengthening and further lengthening is blocked.

Spell-out of (18b)
a. VP: early concatenation
[vP [AdvP k a: le] [AdvP íz[o: lo]]
b. VP: late concatenation
[vP $/ \mathrm{ka}: \mathrm{le} / \sim /$ ízo:lo/]
c. TP: early concatenation
[те /ú-phékê/—/ka:leíz[o:lo/]

It is hence unnecessary to assume any variablity in the phrasing of ajduncts, as the effect follows from the spell-out procedure.

4.1 WhERE'S D?. If PVL is applicable at every cyclic domain, it would be expected to apply within every DP. This is not the case, however, as can be seen from (15a), repeated here as (21) with DPs noted. The expected target within the subject DP is underlined.

(21) (Cheng \& Downing 2007; 53)

$$
\begin{aligned}
& \text { [CP ([DP ízin-g’áne] zi-hlúph' [ [vP [DP ís-álúkwa:zi])]] } \\
& \text { 10-child 10sUBJ-bother 7-old.woman }
\end{aligned}
$$

'The children are bothering the old woman.'

As the complement of D is a spell-out domain, PVL would be expected to apply to the subject in (21). The answer to this question may lie in the structure of the DP and the word building. Following de Dreu (2008), Jones (2018) and Pietraszko (2019), I assume the structure in (22b) for the Zulu DP, where the class prefix is a realization of $n$ and the augment is a realization of D. The root, $n$ and $\mathrm{D}$ are then combined into a complex head, (22c), presumably through some form of lowering or a combination of lowering and raising (e.g., Embick \& Noyer 2001; Harley 2004; Harizanov \& Gribanova 2019). The crucial point is that these heads are specified to undergo whatever operation, or combination of operations, that ultimately results in them forming a complex head (see, e.g., Harizanov \& Gribanova 2019). 
The structure of Zulu DP b.

a. u- m- fazi

AUG- 1- woman

'the woman'

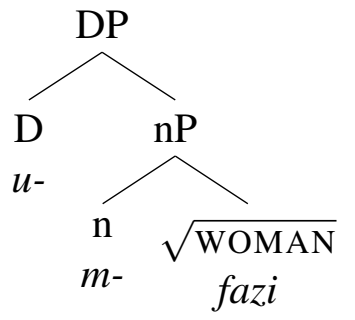

c.

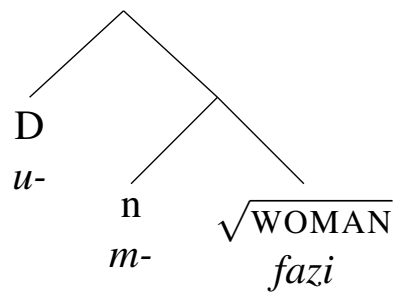

I propose, drawing on, e.g., Svenonius (2016), that in cases where two unmodified heads are merged, i.e. neither head has projected to a phrase, and the two heads are specified to form a complex head, or M-marked (partially borrowing notation from Harizanov \& Gribanova 2019), Merge does not result in a phrase, but a complex head, (23). If one of the heads is modified, i.e. has projected to a phrase, Merge results in a phrase and the heads must be combined postsyntactically, (24).

(23) Merger of two M-marked heads without modification

$$
\mathrm{Y}_{\mathrm{M}}+\mathrm{X}_{\mathrm{M}} \rightarrow[\mathrm{X} \mathrm{Y} \mathrm{X}]
$$

(24) Merger of two M-marked heads with modification

$$
\begin{array}{ll}
\text { a. } & \text { Raising } \\
& \mathrm{Y}_{\mathrm{M}}+\left[\mathrm{xP}_{\mathrm{M}} \mathrm{ZP}\right] \rightarrow\left[{ }_{\mathrm{YP}} \mathrm{Y}_{\mathrm{M}}\left[\mathrm{XP}_{\mathrm{M}} \mathrm{ZP}\right]\right] \rightarrow\left[{ }_{\mathrm{YP}}[\mathrm{Y} \mathrm{Y}+\mathrm{X}][\mathrm{XP} Z \mathrm{P}]\right] \\
\text { b. } & \text { Lowering } \\
& \mathrm{Y}_{\mathrm{M}}+\left[{ }_{\mathrm{XP}} \mathrm{X}_{\mathrm{M}} \mathrm{ZP}\right] \rightarrow\left[{ }_{\mathrm{YP}} \mathrm{Y}_{\mathrm{M}}\left[\mathrm{XP} \mathrm{X}_{\mathrm{M}} \mathrm{ZP}\right]\right] \rightarrow[\mathrm{YP}[\mathrm{XP}[\mathrm{X} \mathrm{Y}+\mathrm{X}] \mathrm{ZP}]]
\end{array}
$$

If PVL is assumed to apply at every spell-out domain, i.e. within the complement of every phase head, PVL is predicted to apply to the phrasal complement of D (cf. Chomsky 2001). As the DPs discussed so far contain no modifiers, the complex head in (22c) directly without ever forming a phrasal structure, (22b). D has no phrasal complement, and the conditions for PVL are not satisfied within an unmodified DP. PVL applies on object DPs as they are targeted at a later cycle. The phrasing of the argument DPs then follows.

This approach receives further support from the phrasing of locative restrictive relative clauses (Cheng \& Downing 2010). Unlike non-locative RRCs shown in (17) ((17b) repeated as (25) below), the head of most locative RRCs (LRRCs), (26) does not phrase with the relative clause and the head undergoes PVL separately.

(25) Non-locative restrictive relative clause (Cheng \& Downing 2007; 53)

(si-thánd' [DP ísí-gqok' ín-dod' é-si-gqok-il ê: -yo])

we-like 6-hat 9-man 9REL-6OBJ-wear-TAM-REL

'We like the hat the man is wearing.'

(26) Locative restrictive relative clause (Cheng \& Downing 2010; 40)

Ngi-thánd' [DP ((í:-ndl') ú-Sípho á-hlálá kú-y o: na)]

I.SUBJ-like 9-house 1-Sipho 1REL-live LOC-9.pronoun

'I like the house that Sipho is living in.'

These effects follow from the approach advocated here under the structures Cheng \& Downing argued for these two types of relative clauses. For RRCs, they assume a head-internal analysis (Cheng \& Downing 2007), following Kayne (1994), (27a). As the head of the relative clause is contained within the $\mathrm{CP}$, the phrasing is expected to follow the pattern observed for sim- 
ple sentences, only a single observable application of PVL is expected. For LRRCs, Cheng \& Downing (2010) assume a head external/empty operator analysis, where the RRC is adjoined to the NP. PVL hence applies within the RC, however, as it is adjoined to the head of the $\mathrm{RC}$, the two will be concatenated under late concatenation. As the NP is modified, D has a phrasal complement and PVL is applicable at the completion of early concatenation. Hence multiple instances of PVL are observable in these these DPs containing LRRCs. The difference in structures is further supported by the lack of reconstruction effects in LRRCs (Cheng \& Downing 2010). Note however that a matching and deletion analysis is also viable in these cases (Sauerland 1998, 2007; Bhatt 2002).

The structure of Restrictive relative clauses
a. Non-locative
[DP [CP HEAD [C RELATIVE CLAUSE]]]
b. Locative
[DP [NP [NP HEAD ] $]_{\mathrm{i} P} \mathrm{NP}_{\mathrm{i}} /$ Opperator $_{\mathrm{i}}$ [C, RELATIVE CLAUSE]]]]

The spell-out of the DP containing the relative clause in (17) as in (28). This cycle spells out the complement of D, i.e., NP, which contains the noun and a CP. The adjunct $\mathrm{CP}$ undergoes spell-out independently as outlined in the previous discussion. At the end of early concatenation PVL targets the the noun, (28a). Subsequently, the head and the relative clause undergo late concatenation, (28b). The VP cycle is skipped in (28) as the VP only contains the object DP. When the TP is spelled out, the verb is concatenated with the phonological string resulting from the previous cycles, (28c). Following this process, PVL is applied, targeting the penultimate vowel of the string. The target has already undergone lengthening and so further lengthening is blocked.

(28) Spell-out of (26)
a. NP: Early concatenation
[NP /í: ndl'/ [CP /úSíphoáhlálákúyo:na/]]
b. NP: Late concatenation
[NP /í:ndl’/ / /úSíphoáhlálákúyo:na/]
c. TP: Early concatenation
[те /Ngithánd'/ /í:ndl'úSíphoáhlálákúy o: na/]

An issue arises however when non-restrictive relative clauses (NRCs) are taken into consideration. NRCs phrase identically to LRRCs, i.e. the head of the relative clause does not phrase with the relative clause and is itself subject to PVL.

(29) Non-restrictive relative clause (Cheng \& Downing 2007; 59)
si-mem' [DP (ú-J a: bu) (o-m-ázi: -yo)] é-dilî:-ni
we-invite 1-Jabu REL.you-1OBJ-know-REL 9LOC-party-LOC

'We are inviting Jabu, who you know, to the party.

Although phrasing of NRCs and LRRCs is identical, Cheng \& Downing (2007) do not assume identical structures. Following Demirdache (1991), they assume that NRRCs are adjoined to DP. 
Non-restrictive relative clauses (Demirdache 1991)

[DP [DP HEAD] [CP RELATIVE CLAUSE ]]

This structure is problematic under the current proposal as it predicts that the head of the relative clause should not be targeted for PVL. None of the DP-internal heads would form phrases as there are no DP-internal modifiers, hence the elements in the extended projection would form a complex head immediately. D, hence has no phrasal complement and PVL does not apply DP-internally. The expected phrasing pattern would be identical to RRCs. Assuming the identical structures for NRCs and LRRCs is not a viable option since, e.g., as a general property, NRCs can modify referential expressions, such as proper names, which RRCs cannot, indicating that NRCs are outside the scope of D (Demirdache 1991).

However, considering the morphological decomposition of the relative marker, NRCs appear to patterns with other DP-internal modifiers, such as adjectives and possessives in carrying the linker $a$ - (see Jones 2018; Pietraszko 2019). When the subject agreement marker on the embedded verb is consonant-initial the $a$ - is visible, as in the case of class 2 subject agreement, $b a$-, becomes $a-b a$-. When the subject agreement marker is vowel initial, the $a$ - linker is obscured by hiatus resolution: when $a$ - is followed by /i/, e.g., class 4 subject marker, the two vowels coalesce into $e-$; when $a$ - is followed by /u/, e.g., class 1 subject marker, the two vowels coalesce into $o$ - (see de Dreu 2008; Jones 2018; Pietraszko 2019 for a detailed overview of this pattern). This indicates that NRCs may in fact be DP-internal elements.

A way of bringing together the phonological phrasing, the morpho(phono)logical, and semantic issues might be adopting a version of Platzack (2000)'s proposal, $(31) .{ }^{8}$ The position of NRCs in (31), similar to LRRCs, is adjoined to an NP, however the NP here is headed by a null $\mathrm{N}$, which takes the relative head as a specifier. The relative clause is then in the scope of a $\mathrm{D}$, hence explaining the morphological decomposition of the relative marker. Following Platzack (2000), the relative head is a full DP, and hence the semantic effects motivating the structure in (30) are achieved as the relative clause is outside the scope of the D associated with the relative head.

(31) Non-restrictive relative clauses (Platzack 2000) [DP $D_{i}$ [NP [NP [DP hEAD] [N, $\left.\mathrm{N}^{0}\right]$ ] [CP RELATIVE Clause ] ]]

Finally, under the structure in (31), NRCs are expected to phrase identically to LRRCs without having to assume an identical syntactic structure or appealing to an intermediate structure. Spell-out of NRCs will hence proceed in the same way as outlined for LRRCs above, (28): PVL applies within the relative clause, as it does within any CP. The NP headed by $\mathrm{N}^{0}$ is modified, hence $\mathrm{D}_{i}$ has a phrasal complement providing context for the application of PVL. As above, PVL applies at the end of early concatenation, but as the relative clause is adjoined, the relative head and the relative clause are not subject to early concatenation. Hence the relative head is targeted for PVL at the end of early concatenation, and multiple applications of PVL are observable.

To summarize, under the approach advocated here, it is possible to maintain the hypothesis that PVL is applied at the end of early concatenation in every cycle while still explaining the phrasing patterns of DPs. When the conditions for the extended nominal projection to

\footnotetext{
${ }^{8}$ Platzack (2000) argues that all RCs are complements of N. Under such an analysis, all RCs are predicted to phrase as RRCs under the current approach.
} 
form a complex head directly are satisified, D has no phrasal complement and hence PVL is not applicable DP-internally. In the presence a DP-internal modifier, as in the case of LRRCs and NRCs, D merges with a structure that has already projected to a phrase, hence providing a phrasal complement and the environment for the application of PVL. Hence all the mismatches between the morphosyntactic and phonological domains observed here are only apparent and can all be computed directly from the morphosyntactic structure.

5. Conclusions. In this paper, I have argued that phonological domains are determined in the same manner at both word- and phrasal level and that apparent mismatches between the morphosyntactic and phonological domains result from the spell-out procedure. Under the assumption that the output of each cycle is included in the spelling out of every subsequent cycle, the appearance of a domain stretching beyond the initial cycle can be achieved while still referencing the morphosyntactic structure directly. Layering concatenation based on selection allows for restricting the range of application within the spell-out domain, giving the impression that the morphosyntactic domain is larger than the domain of (morpho)phonology. Furthermore, by allowing unmodified heads that are specified to form a complex head to do so immediately during the inital merger without first forming a phrasal construction provides a way of accounting for the difference between the phrasing of unmodified DPs and those containing relative clauses. Hence these types of mismatches between morphosyntactic and phonological domains are only apparent and do not provide arguments against a direct reference theory of the syntax-phonology interface. The morphosyntactic structure contains sufficient information to compute the effects of the mismatches.

\section{References}

Adger, David. 2007. Stress and phasal syntax. Linguistic Analysis 33. 238-266.

Anderson, Stephen R. 1969. West Scandinavian vowel systems and the ordering of phonological rules. Cambridge, MA: MIT dissertation.

Árnason, Kristján. 1985. Morphology, phonology and u-umlaut in Modern Icelandic. In Emund Gussman (ed.), Phono-Morphology. Studies in the interaction of phonology and morphology. 9-22. Lublin: Redakcja Wydawnictw Katolickiego Uniwersytetu Lubelskiego.

Árnason, Kristján. 2011. The phonology of Icelandic and Faroese (The phonology of the world's languages). Oxford: Oxford University Press.

Bhatt, Rajesh. 2002. The raising analysis of relative clauses: Evidence from adjectiveal modification. Natural Language Semantics 10. 43-90. https://doi.org/10.1023/A:1015536226396.

Bobaljik, Jonathan. 2000. The ins and outs of contextual allomorphy. University of Maryland Working Papers in Linguistics 35-71.

Bobaljik, Jonathan \& Susi Wurmbrand. 2005. The domain of agreement. Natural Language \& Linguistic Theory 23(4). 809-865. https://doi.org/10.1007/s11049-004-3792-4.

Bobaljik, Jonathan \& Susi Wurmbrand. 2013. Suspension across domains. In Ora Matushansky

\& Alec Marantz (eds.), Distributed Morphology today: Morphemes for Morris Halle. 185-198. Cambridge, MA: MIT Press.

https://doi.org/10.7551/mitpress/9780262019675.003.0011.

Bošković, Željko. 2013. Phases beyond clauses. In Lilia Schürcks, Anastasia Giannakidou \& 
Urtzi Etxeberria (eds.), Nominal constructions in Slavic and beyond. 75-128. Berlin: Mouton de Gruyter. https://doi.org/10.1515/9781614512790.

Buell, Leston. 2005. Issues in Zulu verbal morphosyntax. Los Angeles: University of California dissertation.

Cheng, Lisa Lai-Shen \& Laura J. Downing. 2007. The prosody and syntax of Zulu relative clauses. SOAS Working Papers in Linguistics 15. 51-63.

Cheng, Lisa Lai-Shen \& Laura J. Downing. 2010. Locative relatives in Durban Zulu. ZAS Papers in Linguistics (ZASPiL) 53. 33-51.

Cheng, Lisa Lai-Shen \& Laura J. Downing. 2014. The problems of adverbs in Zulu. In Above and beyond the segments: Experimental linguistics and phonetics. 42-59. Amsterdam: John Benjamins Publishing Company. https://doi.org/10.1075/z.189.04che.

Cheng, Lisa Lai-Shen \& Laura J. Downing. 2016. Phasal syntax = cyclic phonology? Syntax 19(2). 156-191. https://doi.org/10.1111/synt.12120.

Chomsky, Noam. 1995. The minimalist program. Cambridge, MA: MIT Press.

Chomsky, Noam. 2001. Derivation by phase. In Michael Kenstowicz (ed.), Ken Hale: A life in language. 1-52. Cambridge: MIT Press. https://doi.org/10.7551/mitpress/4056.003.0004.

D’Alessandro, Roberta \& Tobias Scheer. 2015. Modular PIC. Linguistic Inquiry 46(4). 593624. https://doi.org/10.1162/LING_a_00195.

de Dreu, Merijn. 2008. The internal structure of the Zulu DP. Leiden University Masters thesis.

Demirdache, Hamida. 1991. Resumptive chains in restrictive relatives, appositives, and dislocation structures. Cambridge, MA: MIT dissertation.

Embick, David. 2010. Localism versus globalism in morphology and phonology. Cambridge, MA: MIT Press. https://doi.org/10.7551/mitpress/9780262014229.001.0001.

Embick, David. 2013. Morphemes and morphophonological loci. In Alec Marantz \& Ora Matushansky (eds.), Distributed Morphology today: Morphemes for Morris Halle. 151-166. Cambridge, MA: MIT Press. https://doi.org/10.7551/mitpress/9780262019675.003.0009.

Embick, David. 2014. Phase cycles, $\phi$-cycles, and phonological (in)activity. In Sabrina Bendjaballah, Noam Faust, Mohamed Lahrouchi \& Nicola Lampitelli (eds.), The form of structure, the structure of forms Essays in honor of Jean Lowenstamm, 270-286. Amsterdam: John Benjamins. https://doi.org/10.1075/1fab.12.21emb.

Embick, David \& Rolf Noyer. 2001. Movement operations after syntax. Linguistic Inquiry 32(4). 555-595. https://doi.org/10.1162/002438901753373005.

Embick, David \& Kobey Shwayder. 2018. Deriving morphophonological (mis)applications. In Roberto Petrosino, Pietro Cerrone \& Harry van der Hulst (eds.), From sounds to structures: Beyond the veil of Maya, 193-248. Berlin: De Gruyter Mouton.

https://doi.org/10.1515/9781501506734-007.

Fenger, Paula \& Gísli Rúnar Harðarson. 2018. Your $n$ s are numbered! On linking morphemes in Dutch. Proceedings of the Linguistic Society of America (PLSA) 3(26). https://doi.org/10.3765/plsa.v3i1.4313.

Grimshaw, Jane. 2000. Locality and extended projection. In Martin Everaert \& Jane Grimshaw (eds.), Lexical specification and insertion. 115-133. Amsterdam: John Benjamins. https://doi.org/10.1075/cilt.197.07gri.

Harðarson, Gísli Rúnar. 2016. Peeling away the layers of the onion: On layers, inflection and domains in Icelandic compounds. The Journal of Comparative Germanic Linguistics 19(1). 147. https://doi.org/10.1007/s10828-016-9078-5. 
Harðarson, Gísli Rúnar. 2017. Cycling through grammar: On compounds, noun phrases and domains. Storrs, CT: University of Connecticut dissertation.

Harðarson, Gísli Rúnar. 2018. Forming a compound and spelling it out. U. Penn Working Papers in Linguistics 24(1). Article 11.

Harðarson, Gísli Rúnar. To appear. Few notes on allomorphy, allosemy and morphophonology. Natural Language \& Linguistic Theory.

Harizanov, Boris \& Vera Gribanova. 2019. Whither head movement? Natural Language \& Linguistic Theory 37(2). 461-522. https://doi.org/10.1007/s11049-018-9420-5.

Harley, Heidi. 2004. Merge, conflation, and head movement: The First Sister Principle revisited. In Keir Moulton \& Matthew Wolf (eds.), Proceedings of NELS 34. Amherst, MA: GLSA.

Hayes, Bruce. 1990. Precompiled phrasal phonology. In Sharon Inkelas \& Draga Zec (eds.), The phonology-syntax connection. 85-108. Chicago: University of Chicago Press.

Ingason, Anton Karl. 2016. Realizing morphemes in the Icelandic noun phrase. Philadelphia, PA: University of Pennsylvania dissertation.

Ingason, Anton Karl \& Einar Freyr Sigurðsson. 2015. Phase locality in Distributed Morphology and two types of Icelandic agent nominals. Proceedings of NELS 45. 45-58.

Jones, Taylor. 2018. An argument for ezafe constructions and construct state in Zulu. Proceedings of the Linguistic Society of America (PLSA) 3(58). https://doi.org/10.3765/plsa.v3i1.4353.

Julien, Marit. 2002. Syntactic heads and word formation. Oxford: Oxford University Press.

Kahnemuyipour, Arsalan. 2009. The syntax of sentential stress. Oxford: Oxford University Press. https://doi.org/10.1093/acprof:oso/9780199219230.001.0001.

Kaisse, Ellen M. 1985. Connected speech: The interaction of syntax and phonology. New York: Academic Press.

Kayne, Richard S. 1994. The antisymmetry of syntax. Cambridge, MA: MIT Press.

Kiparsky, Paul. 1982. Word-formation and the lexicon. Proceedings of the Mid-America Linguistics Conference. http://hdl.handle.net/1808/23139.

Kiparsky, Paul. 1984. On the lexical phonology of Icelandic. In Claes-Christian Elert, Iréne Johansson \& Eva Strangert (eds.), Nordic Prosody III: Papers from a symposium. 135-164. Umeå: Umeå University.

Kratzer, Angelika \& Elisabeth Selkirk. 2007. Phase theory and prosodic spellout: The case of verbs. The Linguistic Review 24. 93-135. https://doi.org/10.1515/TLR.2007.005.

Marantz, Alec. 2001. Words. Paper presneted at the West Coast Conference on Formal Linguistics. Los Angeles: University of Southern California.

Marantz, Alec. 2007. Phases and words. In Sook-Hee Choe (ed.), Phases in the theory of grammar. 191-222. Seul: Dong In.

Marvin, Tatjana. 2002. Topics in the stress and syntax of words. Cambridge, MA: MIT dissertation.

Marvin, Tatjana. 2013. Is word structure relevant for stress assignment? In Ora Matushansky \& Alec Marantz (eds.), Distributed Morphology today: Morphemes for Morris Halle. 79-93. Cambridge, MA: MIT Press. https://doi.org/10.7551/mitpress/9780262019675.003.0005.

Monahan, Karuvannur Puthanveettil. 1982. Lexical Phonology. Cambridge, MA: MIT dissertation.

Moskal, Beata. 2015. Domains on the border: Between morphology and phonology. Storrs: Uni- 
versity of Connecticut dissertation.

Nespor, Marina \& Irene Vogel. 2007. Prosodic phonology. Berlin: Walter de Gruyter.

Newell, Heather. 2008. Aspects of the morphology and phonology of phases. Montréal: McGill University $\mathrm{PhD}$ dissertation.

Noyer, Rolf. 1997. Features, positions, and affixes in autonomous morphological structure. New York: Garland.

Pak, Marjorie. 2008. The postsyntactic derivation and its phonological reflexes. Philadelphia: University of Pennsylvania dissertation.

Pietraszko, Asia. 2019. Obligatory CP nominalization in Ndebele. Syntax 22(1). 66-111. https://doi.org/10.1111/synt.12167.

Piggott, Glyne \& Heather Newell. 2007. Syllabification, stress and derivation by phase in Ojibwa. Montreal: McGill University unpublished manuscript.

Platzack, Christer. 2000. A complement-of-N0 account of restrictive and non-restrictive relatives: The case of Swedish. In Artemis Alexiadou, Paul Law, Andre Meinunger \& Chris Wilder (eds.), The syntax of relative clauses. 256-308. Amsterdam: John Benjamins. https://doi.org/10.1075/la.32.08pla.

Sande, Hannah \& Peter Jenks. 2018. Cophonologies by phase. Proceedings of NELS 48. 39-53.

Sauerland, Uli. 1998. On the making and meaning of chains. Cambridge, MA: MIT dissertation.

Sauerland, Uli. 2007. Unpronounced heads in relative clauses. In Kerstin Schwabe \& Susanne Winkler (eds.), The interfaces deriving and interpreting omitted structures. 205-226. Amsterdam: John Benjamins. https://doi.org/10.1075/1a.61.10sau.

Selkirk, Elisabeth. 2011. The syntax-phonology interface. In John Goldsmith, Jason Riggle \& Alan Yu (eds.), The handbook of phonological theory. 435-484. Oxford: Blackwell. https://doi.org/10.1002/9781444343069.ch14.

Svenonius, Peter. 2016. Spans and words. In Daniel Siddiqi \& Heidi Harley (eds.), Morphological metatheory. 201-222. Amsterdam: John Benjamins. https://doi.org/10.107/la.229.07sve.

Wurmbrand, Susi. 2014. Tense and Aspect in English Infinitives. Linguistic Inquiry 45(3). 403447. https://doi.org/10.1162/ling_a_00161.

Zubizarreta, María Luisa \& Jean-Roger Vergnaud. 2017. Phrasal stress and syntax. In Martin Everaert \& Henk van Riemsdijk (eds.), The Wiley Blackwell companion to syntax (Second edition). 1-52. Hoboken, NJ: Wiley Blackwell.

https://doi.org/10.1002/9781118358733.wbsyncom050. 